\title{
NORTH ATLANTIC TREATY SECURITY
}

\author{
Col. Navigator Bogdan GRENDA, DSc \\ War Studies University, Warsaw, Poland \\ b.grenda@akademia.mil.pl
}

\begin{abstract}
The article discusses security within the North Atlantic Treaty Organisation with respect to threats which may appear in its near and more distant surroundings. The following military threats are discussed: military conflicts, militarization of the Arctic, demonstration of Russian military power, use of weapons of mass destruction, cyber attack, terrorism and militarisation of Space. Other mentioned dangers are: natural and social ones including migration, competition among state and non-state entities as well as the phenomenon of fallen cities and states.
\end{abstract}

Key words: threat, conflict, militarisation, security.

\section{Introduction}

Threats to security are mostly determined by the modern security environment and derive from challenges and wasted chances in political, economic, military, social, ecological, cultural, ideological and other areas. Despite efforts to eliminate all occurrences of international aggression, we are continually witnessing various military conflicts. In the past 50 years there were over 200 of them. People are still being killed and the human achievement of many years is wasted.

The growing overpopulation on Earth is increasingly generating famine, industrial pollution and ethnic conflicts. As a result of these, some countries tend to arm 
themselves excessively, seeing military action as the best way to solve accumulating problems.

The late 20th century witnessed the rise of numerous new states which are often politically and militarily unstable, bringing about rather pessimistic reflections regarding the future of the world. Although the apocalyptic vision of the global use of nuclear weapons makes us believe that they never will they be used, we cannot exclude new military conflicts in modern international relations. The experience of modern wars shows that they embrace all fields of human activity and that military clashes occur in all possible dimensions. NATO identifies the future as more and more complicated and insecure, presenting challenges and opportunities whose driving force is the fast pace of social, economic, scientific, technological development as well as changes in environmental protection. Therefore, the main purpose of the article will be to identify situations which may destabilise the security provided by the North Atlantic Treaty.

\section{Identification of Threats to NATO Security}

One of the most probable scenarios envisages State-versus-State Conflict, namely escalation of conflict from the countries neigbouring NATO, and also these conflicts staying "frozen", a war of country against country including situations from article 5 of the Washington Treaty, as well as wars over new spheres of influence. The following selected conflicts taking place in NATO's neighbourhood may become a threat in the event of their internationalisation:

- Crimean conflict between Russia and Ukraine;

- conflict situations within the area of former Yugoslavia;

- national and ethnic conflicts within the area of the former Soviet Union (Chechnya, Upper Karabakh, South Ossetia, Abkhazia);

- disputes about the civic rights of Russian people in Estonia and Latvia, the Hungarian minority in Slovakia and Kurdish people in Turkey

- War in Syria.

Another unstable situation arises from the conflict in the Euro-Atlantic region as a result of expansion on the borders of NATO, and rebellion on a large scale within NATO. This may be caused by lack of balance in military power, 
division and break-up of NATO. Moreover, it may originate from some internal or external entities. An example of a crisis between member states of NATO is the "smouldering" Cyprus conflict between Greece and Turkey. Long-standing division of Cyprus into Greek and Turkish sectors exerts enormous influence not only on the relations between these two countries, but also on the relations in the region. In March 2016, at the NATO forum, Turkey contested the territorial supremacy of Greece over an archipelago of small islands and the air space over the Aegean Sea surrounding it. This tense situation between two members of NATO also poses a threat to Treaty stability and the security of the region.

The increasing Russian military strength is one of the main hazards ${ }^{1}$ for the security of NATO. For over a decade, Russia has consistently carried out a policy of rebuilding her strategic position in Eurasia, which she lost after collapse of the Soviet Union, with the extensive influence zone reaching far into Eastern and Central Europe as well as Central Asia. The main means used by Moscow are its increasing political aggression towards international milieu and the escalating dependence of West European countries on the supply of Russian energy resources. It is noteworthy that Russia has never stopped perceiving NATO as its geopolitical opponent. In spite of formally quite good cooperation with NATO, Russia has unalterably considered NATO as the primary threat to her position in the area of Eurasia for the last two decades. This perception is deeply rooted in Russian geopolitics which have been, almost since the beginning of its history, exposed to strategic pressure from the west, and it was there that she strove to create its geopolitical foreground (buffer). One example of such actions is Russia taking military control over the Crimean Peninsula. On the night of 27th to 28th February 2014, the Russians relocated their forces to the peninsula under the guise of a military exercise, concealing the real nature of the move, and developed military infrastructure in the region. Their next step was to cut off communications between Ukraine and Crimea and starting a cyber war in order to isolate the peninsula. The activity in the Crimea was accompanied throughout by increased military activity in the area of the Russian Federation (Western

1 According to the definition "threats are situations where there is a probability of a dangerous event for the surroundings. This is an indirect or direct destructive action towards the object", M. Huzarski, AON, Warsaw 2009, p. 12. 
Military District) ${ }^{2}$ and in the Ukraine (Kherson, Zaporizhia, Donetsk, Luhansk and Kharkov oblasts). In both cases, the undertaken steps evidenced preparation for possible escalation of the conflict.

It must be also emphasised that Russia has conducted an ambitious plan since 2008 to modernise its military forces (among other things it made provisions for equipping armed forces with 70\% modern equipment up to 2020), increased expenditure on defence (2008-2014, the Russian budget was raised over two times). In 2014, Russia approved modernisation of its Military Forces with 84.5 billion dollars, which is $8.1 \%$ more than in 2013. In spite of economic trouble caused by the embargo and huge drop in petrol and gas prices, the Kremlin expended armaments in 2015 by only 5\% less, around 81 billion dollars, and the total expenditure in dollars is to be again similar in 2016 and amount to 85-90 billion. Russia is constantly developing fast military mobilisation capability on NATO's borders, violating the air space of member states and testing air defence systems, developing nuclear potential and making military threats against $\mathrm{NATO}^{3}$.

Access and use of global resources is another scenario, including challenges connected with the access and use of resources by NATO. There has been a considerable increase in hazards for the global turnover of resources, including an increase in hazards connected with lack of resources (and access to them), climate change, creation of new disputable regions and rising hazards for transport routes and global trade.

In recent years, the threat of military confrontation over the North Pole has increased. The struggle for the Arctic is a battle for enormous deposits of gas and petrol estimated at 10 to $15 \%$ of world resources of natural gas and $30 \%$ of petroleum. There are also rich deposits of rare minerals (zinc, manganese, lead, platinum, and gold) in the same area. The second axis of territorial disputes over the Arctic is the problem of "Northern Passages". The melting ice cap on the Arctic Ocean waters makes the plans to use this basin for the needs of international

2 Since 26th March, Russia concentrated in the Western Military District along the border with Ukraine considerable land military forces of 30-40 thousand soldiers including armoured and artillery troops pretending to organise a military exercise. A similar sized army was waiting inside the country ready to be transferred to the border between Russia and Ukraine.

3 http://tvn24bis.pl/z-kraju,74/wydatki-na-zbrojenia-kto-placi-najwiecej,532832.html. 
sea trade more and more real. The Northern-Eastern Passage stretching from Murmansk on the Barents Sea, through Siberia up to Bering Bay, the NorthEastern and surrounding arctic shores of Canada and Alaska, and the NorthWestern Passage are being more and more seriously treated as potential new trading routes between the Atlantic and the Pacific ${ }^{4}$.

The Disruptive Impact of Mass Migration is defined as causing instability for countries and the Treaty. The uncontrolled flow of refugees, migrants and economic immigrants have become a threat. Civil war in Syria ${ }^{5}$ started in 2011 and led the country to anarchy which has become less and less manageable for the goverment of Bashar al-Assad. Since that moment, Syrian people started to flow into Europe trying to obtain political asylum. The deteriorating domestic situation of the Syrian state is being used by external people, such as the terrorist organisation originating from the Sunni party (the so called"Islamic State of Iraq and Syria, ISIS") and the Al-Qaeda group striving to extend their influence. Consequently, the migration of people from this Islamic state engulfed in internal conflict began. Therefore, it is impossible to exclude the option that fighters from those extremist groups have penetrated into Europe, increasing the terrorist threat for NATO countries. Islamic extremism and terrorism is a new factor more and more clearly silhouetted on the horizon as a threat to the security and stability of NATO member states. Islamic radical vision, openly anti-West, is proclaimed by extremist Sunni Islamic organisations reaching for terrorism as their main method of attack. It is a relatively new threat with no classical military character and difficult to conceptualise in the framework of classical geopolitics because it comes from persons outside of the state acting without connection to the activity of particular countries.

4 M. Wrzosek, Nowe i stare zagadnienia Sojuszu Pólnocnoatlantyckiego, Zeszyty naukowe AON nr 2/2013, p. 33.

5 The civil war in Syria was inspired by the success of the Arab Spring, including the fall of the government of President Hosni Mubarak in Egypt, and was started as a result of the discontent of Syrian society with the form of government of the Baas Party, since 2000 with President Bashar al-Assad at its head. The impulse for its break-out was the self-immolation of a Syrian citizen, Hasan Ali Akli, in January 2011 as a sign of protest against lack of state reform. This act resulted in the outbreak of social protest striving to overthrow the existing government. Following that, a series of protests started which soon led to a regular fight with the army faithful to Bashar al-Assad. 
Importantly, the threat comes not only from outside of the treaty area (mostly from the Middle East, South Asia or North Africa) but also from within - from increasingly active and aggressive communities of Muslim immigrants and their descendants (especially in Western Europe). It is also worth emphasising that the influx of population from the Middle East with completely different culture and system of values into European communities results has the potential to result in violence e.g. immigrants clashing with local police or inhabitants. The outcome can be damage to elements of municipal infrastructure or private property of city dwellers.

High Impact Cyber Threat is a scenario of cyber-attack on a large scale on a member of NATO and its structures ${ }^{6}$. This type of threat may arise as a result of challenges using cyberspace, fighting in cyberspace or the use of false identities ${ }^{7}$.

Attacks in cyberspace ${ }^{8}$ have become more and more frequent and unpredictable. Most breaks into NATO systems are now acts of cyber espionage (information aquisition) and cyber-vandalism (blocking access to web pages, changing their content, data destruction). We cannot exclude the option that in the future, offensive action in cyberspace may destabilise the functioning of NATO during peace or military conflict. Countries like China, Russia and Iran are developing such abilities and the conflicts in Georgia and Ukraine testify to the progressing coordination of virtual and conventional operations. The main targets would be military networks and systems of civilian critical infrastructure. The control over these or erasing or manipulating data may paralyse command and communications systems, detection, logistics and others and, therefore, have an impact on the operational capacity of armies. The problems of cyberspace defence in NATO following increasing threat are a priority, which was mirrored in a sequence of declarations issued after the NATO summits in Lisbon, Chicago, Newport and Warsaw. According to the new Strategy Concept and updated NATO Policy on cyber defence, the Treaty defines cyber threats as a potential reason for collective

6 D.C. Lovelace, Terrorism: Commentary on security documents volume 146: Russia's resurgence, Oxford 2017.

7 This concept includes the ease of masking one`s identity, commitment, anonymity on the internet, and identity theft person, institution, and organisation).

8 The definition of cyberspace refers to imagined milieu where digital information is made accessible by computer networks. Source: National Military Strategy for Cyberspace Operations - NMS-CO Joint Chiefs of Staff, Washington 2006, p. 5. 
defence according to NATO article 5. Apart from doctrinal solutions, a few actions have been taken in the area of organisation, including creation of the Cyber Defence Centre of Excellence - CCD COE in Estonia99.

Also, some other NATO countries recognised the need to set up a national system of self defence against cyberspace threats. Such countries as the USA, France, Great Britain, Germany and others have already laid out their ways and methods for acting in the event of attacks on their critical ICT infrastructure. The next step is the creation of possibilities for offensive, anticipatory actions in cyberspace.

The use of Weapons of Mass Destruction is a scenario envisaging attacks on NATO by terrorist groups by means of mass destruction weapons or attacks on the outskirts of NATO that have an impact by causing crisis on its borders. In the new environment of threats to international peace and security, unconventional weapons take priority. They include nuclear weapons, radiological, chemical and biological weapons and the means of their transport.

Nuclear weapons have been possessed by developed countries since the mid1940s. Knowledge about their effect has been one of the most important elements discouraging their use.

The situation looks different among the less developed countries which, for years, have been in conflict with other countries. These countries intensively look for opportunities to take possession of nuclear weapons, allowing them to achieve a dominant position in their region. Meanwhile, they would develop much cheaper programmes of chemical and biological weapons of mass destruction. Such situations have occurred in Iran, Syria, Libya, Iraq, India, Pakistan and North Korea ${ }^{10}$.

9 B. Grenda, Cyber-bezpieczeństwo operacji powietrznych NATO, in R. Czulda, R. Łoś, J. Reginia-Zacharski (eds), NATO wobec wyzwań wspótczesnego świata, Warsaw 2013.

10 The greatest fear may be caused by the situation in Iran where large amounts of chemical weapons have been gathered for a long time and now, through various investments and staff training in foreign centres, full independence in the production of nuclear fuel is being sought. Other dangerous tendencies have also appeared in India and Pakistan, competing for decades for primacy in the region and successfully developing programmes of all three kinds of mass destruction weapons and their carriers. 
It must be noted, of course, that the above mentioned countries do not even indirectly pose a threat to the security of NATO. Nevertheless, such threat may become active in the event of loss of control over those means and they being taken over by terrorist organisations even in a limited way, which seems quite probable in some regions.

Potential use of those weapons by terrorists has been recognised as one of the most serious challenges for the modern world, and the use of nuclear weapons, even if it was a primitive nuclear charge, depending on its force and place and time of explosion, would undoubtedly result in most grievous consequences, not only because of unimaginable destruction and a huge number of victims and most probably ecological catastrophe, but also through unprecedented political, social and economic effect. We cannot forget the psychological aspect of nuclear terrorism, particularly the psychosis connected to nuclear weapons which may cause political change just by the threat of using them or by the sheer fear of them.

This fear, verging on panic and transformed into universal hysterics, is a threat to the functioning of society as much as terrorists are. Much has been said and written not only about potential use of a nuclear explosive charge by terrorists, but also about the threat of terrorism using a simpler solution: a radiological weapon. It seems a simpler solution for terrorists to construct so called dirty bombs or to steal one of notorious "suitcase" nuclear bombs produced in the former Soviet Union for KGB needs and intended for sabotage actions against Western countries.

The next scenario assumes Space Capability Disruption, identified as to the loss of ability to use Space and, therefore, enhanced vulnerability ${ }^{11}$. In 1960, the US President, John F. Kennedy said that "the country which will be the first to dominate in the space will also dominate the Earth". Today nobody is astonished by the statement that the country which has the opportunity to freely use satellite resources will prevail over those who do not have them. Therefore, the possession of appropriate military resources in Space is an important element of 21st century strategy. The current level of space technology ensures not only the impact from

11 J.J. Klein, Space warfare: Strategy, principles and policy, London 2006. 
Space on military action on the Earth, sea and in the air, but it is expected that a few subsequent measures and aspects of striking may be used for destroying objects and long range ballistic rockets in Space ${ }^{12}$ :

- laser weapons - where the energy carrier is a stream of photons travelling at the speed of light- kinetic weapons - where destructive possibilities result from the powerful energy of projectiles because of their enormous speed;

- particle weapons - where the possibility of great acceleration of charged particles is used in this way, endowing them with great energy;

- radiation weapons - impacting the target with something other than light energy, for example electromagnetic;

- direct ways - where destruction of the target takes place through direct strike of one object onto another without an explosive (battering).

Large-Scale Disasters include identified threats such as natural disasters on a large scale, things taking advantage of chaos, pandemics hitting the Treaty countries and hostile action and reductions in global financial centres. Based on analysis of past disasters and break-downs, the following extraordinary threats for NATO security may be detailed

- radioactive pollution;

- explosions, vast fires, construction and transportation disasters;

- biological contamination of people, animals and plants;

- natural threats.

Radioactive pollution has a limited range and may appear in isotope laboratories and in medical plants. Ionising radiation is used by industrial establishments: the health service, medical equipment, $\mathrm{X}$ rays, which is a source of threat for both staff and patients. Radiation pollution may also come from nuclear power plants. There are around 228 nuclear plants in Europe now, including 26 active ones where each year hundreds of failures happen. There are also many plants in Europe with dangerous industrial agents in quantities posing an enhanced risk of failure which, as a consequence, may lead to general contamination with toxic industrial substances. The essential characteristics of chemical compounds are:

12 Considerable fall of value of securities causing financial crisis, breakdown on stock markets, financial speculation, and economic crisis. 
- they can easily evaporate into the atmosphere;

- the dominant syndrome is during acute contamination;

- substances with predominant suffocating action: chlorine;

- substances with the predominance of those acting on all organisms: prussic acid, carbon monoxide;

- substances with suffocating action and on all organisms: nitrogen oxide, sulphur dioxide, nitrogen acid, hydrogen fluoride;

- substances acting by sending out and transmitting nerve impulses: carbon bisulfide, tetraethyl lead;

- substances with suffocating and neurotropic action: ammonia;

- metabolic poisons;

- substances disturbing exchange of substances.

Biological weapons are one of the most important threats both for armed forces and civilians and their use, even if it occurs in a distant country, may also spread elsewhere. Massive and fast migration of people could result from this. A terrorist attack using biological weapons may occur through aerosol spraying, contamination of food or water, or unconventional methods. Such methods may be contaminated postage or everyday objects, e.g. with cyanide (used by the Tunisian and Moroccan groups) or ricin (used in the UK) ${ }^{13}$. The targets of such bioterrorist attacks may be, first of all, places where a great number of people are assembled (e.g. shopping centres, underground stations, railway stations, and airports) and also army groups.

The greatest threat from explosions is caused by intentional placement of explosives. Placement of explosives which are supposed to go off in order to cause damage to people and property are considered in military art as a strike (destructive action at the enemy forces and resources.) This is a new element in the modern world which may be encountered by state military forces and the police. Planting a bomb, as this criminal activity is commonly named, is for many a synonym of terrorism. The main part of the bombs used by terrorists is an explosive, explosive material in grenades, mines etc. or in the form of bricks designated to destroy enemy targets and troops. In the case of terrorist actions, the quoted definition

13 E. Karmon, Weaponry, doctrine and operational consequences, in M. Edmonds (ed.), Future NATO Security, Amsterdam 2004. 
can be the basis to define the so called improvised explosive device which is made by using explosive for construction of unconventional devices for destruction of objects and persons targeted in criminal acts. The characteristics of improvised explosive devices are as follows:

- construction based on individual imagination;

- independent source of energy;

- temporal or remote control initiating devices which allow the offender to leave the place of explosion safely.

This type of bomb is often produced with the use of an explosive of great force produced at home. The most dangerous one commonly used by Palestinian terrorists is known as TATP (triaceton triperoxide) ${ }^{14}$.

Threats from forces of nature are long term rainfall, droughts, heavy frost, snow storms, hail storms, hurricanes, and thunderbolts which may cause fire. Floods following rainfall, thaw or strong winds are a great threat. The scale and time of these threats is changeable.

Non-State Actors Rival State is a scenario identified as an attack on critical infrastructure as well as the rise of virtual organisations, climate change, competition in the creation of best strategy and position on the market, ongoing social changes contrary to the national attitude, collapse of existing state structures and creation of new ones, dependence of critical infrastructure, and the collapse and upheaval of political structures. Furthermore, a scenario of a country pitted against non-state entities should be considered as well as the use of destructive technologies by groups representing a "different line of thinking".

Mega - city Turmoil ${ }^{15}$ caused by a maelstrom in major cities and large metropolises as a result of national state inability to secure safety, satisfying the basic needs of the population and the rise of urbanisation and competition for access to resources. These situations may lead to the rise of "fallen cities" 16 and so called fallen states or inefficient states. This situation refers not only to Africa, but an example of a European state which cannot cope with its various problems of political,

14 TATP - Improvised Explosive. Overview, Tel Awiw 1998, p. 2.

15 Large cities and mega cities defined as metropolises with over $10 \mathrm{~m}$ inhabitants.

16 Rise of non-governed structures, devoid of legal regulations etc. 
economic and ethnic nature is Bosnia and Hercegovina. This state, born almost 20 years ago after the break-up of Yugoslavia, has the poorest society in Europe and the most elaborate official apparatus on the Old Continent. It is an example of a state beset by "institutional paralysis" caused by ethnically conditioned tri-part goverment (every position is held by three officials representing Serbs, Croats and Bosnians). An additional factor destabilising the situation in this country is wide-spread corruption, privatisation of the public sector carried out quickly and the ensuing mass reductions of workers as well as a large number of people with the mentality for blaming the European Union, which initiated the process of selfreliance in Bosnia and Hercegovina, for their failures.

\section{Conclusions}

In the future, NATO may encounter either a "state" opponent or an opponent consisting of non-state entities which will be acting independently or jointly against the Treaty. The opposing countries may use non-state bodies in order to avoid responsibility for their actions. Non-governmental entities are more difficult to identify and stop because they may conduct their activity using forces and resources which will not be able to be countered with "classical" armed forces. They may use asymmetrical actions or irregular forms of combat against the Treaty in order to counter NATO's military advantage.

Some countries or non-governmental entities may strive to join together various methods of combat: conventional, irregular, and elements of cyberspace war. It is also possible to use large scale acts of violence or terrorism. This hybrid and nonunequivocal model of action may also complicate the process of agreement within the boundaries of the Treaty, make it difficult to choose strategy, and complicate the process of defensive planning because it blurs the borders for use of force by traditional methods. 
Apart from the traditional area of operation, military action in the future will probably also be conducted in ungoverned ${ }^{17}$ areas in large cities in an area with difficult access in the field of global natural resources ${ }^{18}$. Action in these fields and the reasons for NATO conducting it may test its determination and unity as well as crossing the Traditional Euro Atlantic territory where NATO may not have clearly defined legitimacy or jurisdiction.

An opponent attacking NATO will probably try to destroy its integrity. Apart from conventional military operations, future action may also include special operations, and operations of irregular forces (use of mercenaries, terrorists and criminal organisations). The conducted operations will also include psychological and offensive actions in cyberspace and propaganda using social media. As a result of access to a more and more extensive gamut of new functions and technology of the future, connecting old and new methods of combat, so de facto creating hybrid threats, future opponents may considerably increase their potential and so increase the threat to NATO.

\section{Bibliography}

Grenda B., Cyber-bezpieczeństwo operacji powietrznych NATO, in R. Czulda, R. Łoś, J. Reginia-Zacharski (eds), NATO wobec wyzwań wspótczesnego świata, Warsaw 2013.

Huzarski M., Zmienne podstawy bezpieczeństwa i obronności państwa, AON, Warsaw 2009.

Huzarski M., Zagadnienia taktyki wojsk ladowych, Torun 1999.

Karmon E., Weaponry, doctrine and operational consequences, in M. Edmonds (ed.), Future NATO Security, Amsterdam 2004.

Klein J.J., Space warfare: Strategy, principles and policy, London 2006.

Korzun M., 1000 stów o materiałach wybuchowych i wybuchu, Warsaw 1986.

17 The territory not regulated by any rules - may rise on crisis areas or war areas e.g. fallen cities.

18 If we leave out natural resources on the areas belonging now to state entities we may indicate not discovered or legally yet disallowed to exploit areas of oceans and seas as well as the Arctic and the Antarctic. An example of many such actions is a struggle for the Arctic. The Russian federation increased the number of its troops in the polar circle and Canada demanded for their own the North Pole. The reason is the enormous deposits of natural resources (gas, petrolium and rare metals) under the thick ice cap. 
Langbein K. et al., Bioterroryzm, wyd. Muza s. a., Warsaw 2003.

Lovelace D.C., Terrorism: Commentary on security documents volume 146: Russia's resurgence, Oxford 2017.

National Military Strategy for Cyberspace Operations - NMS-CO. Joint Chiefs of Staff, Waszyngton 2006.

Regulamin działań taktycznych Wojsk Ladowych, cz. II (pododdziaty), Warsaw 1994.

TATP - Improvised Explosive. Overview, Tel Awiw 1998.

Wrzosek M., Nowe i stare zagrożenia Sojuszu Północnoatlantyckiego, Zeszyty Naukowe AON nr 2/2013.

http://tvn24bis.pl/z-kraju,74/wydatki-na-zbrojenia-kto-placi-najwiecej,532832.html 